\title{
Minimally Traumatic Surgical Procedures in Periodontics: a Review
}

\section{Procedimentos Cirúrgicos Minimamente Traumáticos em Periodontia: Revisão de Literatura}

\author{
Humberto Osvaldo Schwartz-Filhoa; William Cunha Brandta*; Caio Vinicius Gonçalves Roman-Torres ${ }^{\mathrm{a}}$ \\ ${ }^{a}$ University of Santo Amaro, Department of Dentistry, Section of Implantology, SP, Brazil \\ *E-mail: williamcbrandt@yahoo.com.br
}

Received: January 3nd, 2014; Accepted: March 3rd, 2014

\begin{abstract}
The concept of minimally invasive procedures can be extended to all fields of dentistry. Periodontics, in particular, has been reported as one of the areas with great benefits. This review aims to describe the use of minimally invasive procedures in periodontal surgery, its concepts, applications, and possible benefits from its use. For that, 682 articles published between 1950 and 2012 focused on minimally invasive periodontal surgery were evaluated. Of them, 669 studies did not describe clearly the procedures, and did not attend the inclusion criteria. The results showed that proper lighting promotes increased visual acuity during surgical procedures, favoring the precision associated with microsurgical instruments specifically designed, allowing a more accurate manipulation of the soft and hard tissues. Surgical access avoids unnecessary tissues removal, optimizing the debridement, improving vascularisation, and therefore the possibility of obtaining primary healing of surgical wounds. The microsurgical approach can improve the predictability of different periodontal procedures, providing better results and cause less postoperative discomfort. However, few controlled methodologies on the use of instruments to promote minimally invasive procedures in periodontics have been found in literature. Therefore, studies are needed to determine whether microsurgical techniques can lead to a significant difference in the successful outcome. Most of the studies are based on observations and experiences of the authors, which clearly show that there are advantages in having better lighting, better vision, and a more controlled and less traumatic technique.
\end{abstract}

Keywords: Gingival Recession. Gengivoplasty. Wound Healing.

\section{Resumo}

O conceito de procedimentos minimamente invasivos pode ser estendido a todas as áreas da odontologia, mas a periodontia, em especial, tem resultados benéficos quando da utilização desta modalidade terapêutica. Dessa forma, esta revisão de literatura teve como objetivo descrever a utilização dos procedimentos minimamente invasivos em cirurgias periodontais, seus conceitos, aplicações e possiveis beneficios. Para esta revisão de literatura, foram avaliados 682 artigos publicados entre 1950 e 2012 que abordaram o tema cirurgia periodontal minimamente invasiva. Destes 682 artigos, 668 não descreveram claramente os procedimentos realizados não atendendo aos critérios de inclusão e portanto foram descartados. Cuidados como iluminação adequada promovem um aumento da acuidade visual durante os procedimentos cirurgicos, assim favorecendo a precisão associada aos instrumentos microcirúrgicos especificamente concebidos e permitindo uma manipulação mais precisa e minimamente traumática dos tecidos moles e duros. Além disso, auxilia na melhora do acesso cirúrgico, evita a remoção desnecessária de tecidos, a optimização do desbridamento, melhora a vascularização e, por conseguinte, a possibilidade de obtenção de cicatrização primária de feridas cirúrgicas. A abordagem microcirúrgica pode melhorar a previsibilidade dos diferentes procedimentos periodontais, proporcionar melhores resultados estéticos e causar menor desconforto pós-operatório. No entanto, poucos estudos foram realizados com metodologias estabelecidas sobre o uso de instrumentos que promovam procedimentos minimamente invasivos em periodontia. Portanto, são necessários estudos para determinar se as técnicas microcirúrgicas podem levar a uma diferença significativa no prognóstico da terapeutica proposta. A maioria dos estudos encontrados na literatura são baseados em observações e experiências dos autores, que mostram claramente que há vantagens em uma melhor iluminação, melhor visão e técnica mais controlada e menos traumática.

Palavras-chave: Retração Gengival. Gengivoplastia. Cicatrização.

\section{Introduction}

The concept of minimally invasive procedure is more directly related to removal of caries and cavity preparation. However, despite the great progress and development of the operative dentistry, the concept of performing less invasive procedures can be extended to other areas of dentistry. Periodontal procedures using microscopic instruments such as flap surgery, gingival coverings and regenerative procedures are less invasive, they they were included in the concept of minimally invasive procedures in dentistry.

The concept of operative microscopy was introduced relatively recently in the field of dentistry. Despite the use of the microscope is well defined in medical use, it was introduced later in dental practice. The use of magnification for surgical procedures was introduced into medicine during the late nineteenth century, when Barraquer ${ }^{1}$ started to use it to corneal surgery during the 50's. Despite the success and some interventions, the use of the microscope in surgery was widely accepted in medicine only in the 60's, when Jacobsen and Suarez succeeded with revascularization in suturing blood vessels ${ }^{2}$.

In the last four decades innovations in the use of the 
microscope for laparoscopy, arthroscopy, neurological and vascular surgery have been proposed. Apotheker \& Jako were the first to introduce the microscope in dentistry in 1978. In 1992, Carr $^{3}$ suggested the use of the microscope during endodontic procedures. In 1993, Shanelec and Tibbetts were the forerunners of the use of this tool in periodontics ${ }^{2}$.

The use of the microscope was accepted with caution in dentistry. There is a gap between changing scientific concepts, and refine this change through research showing its advantages, finally leading to acceptance or rejection of the technique. This last step on the use of the microscope or not in periodontics will be addressed in this study. Thus, the present review aims to study the use microsurgery for minimally invasive surgical procedures in periodontology describing their concepts, application, and possible benefits from its use.

The role of surgical techniques in periodontics is very well established within a periodontal treatment plan. Once the necessity of employing a particular surgical technique is established, the correct planning and execution of the technique, and postoperative control is the focus to achieve the results expected with the procedure. This is dependent on the scientific knowledge of the professional regarding: diagnosis, treatment plan, repair, besides the professional decisions, skill, and training.

Since the beginning of the dental practice, the light to viewing the work has played an important role. Optic fiber technology has favoured the methods of focusing specific areas, being used in operative surgical microscopes, allowing a light field without shadows.

Magnification may be obtained through the use of dental loupes, but only to a limited extent. The use of high magnification loupes becomes uncomfortable because of their weight and difficulty of maintaining stable movements of the head and neck muscles. As the microscope is not directly connected to the body, its weight has no influence on the operator and the field of vision remains stable. Most microscopes are capable to increase greater than $20 \mathrm{X}$ magnification, whereas the ideal magnification in periodontics may be between $5 x$ to $12 x^{4}$. The synergism of adequate lighting and an increase in visual acuity can favor precision in surgery. The increase in accuracy has led to more precise surgical incisions, and less traumatic and faster post-operative repair, besides promoting a precise positioning of the tissue and use of smaller sutures and needles. The increased visualization of the root surface also facilitates the removal of calculus, and a further flat surface is obtained.

The enhanced visual acuity provided by using an operating microscope (i.e., magnification and improved illumination of the field), associated to specifically designed microsurgical instruments, allows a more accurate and manipulation of the soft and hard tissues, improves the surgical access and avoids unnecessary removal of tissues, optimizes the defect debridement and the root instrumentation, improves vascularization, and enhances the mobility of flaps and, hence, the possibility of obtaining primary wound closure. Therefore, a microsurgical approach may improve the predictability of different periodontal procedures, providing better esthetic results, and causing less postoperative discomfor $\mathrm{r}^{5-8}$. When using the microscope, the immobilization of the patient's head may be considered, once it can prevent problems in the incision, tissue tearing, or damages during the implementation of the proposed technique . $^{8}$

According to Tibbets and Shanelec ${ }^{8}$, the microscope enables professionals a better posture, comfort and long-term health, since dentist stays in inappropriate positions by a large period.

Several types of optimized blades provide greater precision in incisions. Dimensions may vary around $2.4 \mathrm{~mm} \mathrm{x}$ $3.7 \mathrm{~mm}$, facilitating less invasive incisions, preventing injuries and promoting faster tissue repair. Besides the blades other instrument shave been developed for use in microsurgery, including needle holder, forceps, retractors and scalpel cables. The use of smaller instruments under magnification refines the movements of the surgeon, increasing surgical precision ${ }^{7}$.

The main goals of surgery are, wherever possible, completely close the incisions performed after treatment, with an appropriate tension and immobilized flap. Selecting an appropriate combination of the needle and the thread provides the surgeon with an accurate positioning and closing the tissue margins with minimal trauma and in this aspect microsurgery may increase the options of needles and sutures of appropriate size. The use of smaller needles (10-0, for example) minimizes the inlet orifice of the needle thus reducing the trauma to the tissues ${ }^{2}$.

\section{Development}

\subsection{Methods}

Studies on this subject from 1950 to 2012 were selected in the bibliographic database PubMed (www.ncbi.nlm.nih. gov/pubmed) (U.S. National Library of Medicine), Lilacs, Scielo, using the following terms alone or in combination: Surgical procedures, minimally invasive; Gingival retraction; Gengivoplasty; Wound healing.

The selection criteria were assessed by the titles and abstracts on the subject proposed. Eligibility criteria included both animal and human studies, review and case reports articles.

The search strategy initially yielded 682 references, whose titles and abstracts were reviewed by two authors. Then, 602 studies that did not clearly address the relationship between surgical procedures and minimally invasive techniques were discarded. The remaining 80 articles were selected and 14 articles were the basis for this review. The factors related to the different instruments and techniques used in the implementation of therapy, duration of surgery, healing and possible postoperative complications were investigated. 


\subsection{Discussion}

Few studies on microsurgery are found in the literature. Thus further case-control and longitudinal studies are needed to determine whether microsurgical techniques can lead to a significant difference in surgical results with benefits to the patient.

No controlled study to date showed the real importance to use or not the microscope in periodontics, once the studies found in the literature do not use control groups without using the microscope, and the findings are based on observations and experience of the authors. However, there are very clear advantages of having better lighting, better vision, and a more controlled and less traumatic technique.

Microsurgery gives more predictable results and is applicable to periodontal flap surgery for better control and less tissue trauma. It is a transition and an extension of the existing surgical techniques, and represents an evolution, since it is less invasive and favors faster repairs. It provides better aesthetic results and less discomfort to patients due to minor trauma ${ }^{6,9,10}$. Microsurgery favors the recognition of subgingival elements, facilitates adaptation of the flap in primary wounds, thus decreasing the healing time, pain and patient discomfort ${ }^{8}$.

Few established methodologies on the use of periodontal microscopy are found in literatue. One cause of the failure in guided tissue regeneration - GTR may occur in the exposure and contamination of membranes, which is not directly related to difficulties during coaptation edges of the sutures. Microsurgery could facilitate coaptation, thus improving the GTR results. Cortellini e Tonetti ${ }^{11}$ investigated 26 patients who underwent GTR associated with microsurgery, and found that $92.3 \%$ of the sites remained closed without exposure of the membranes. The authors concluded that an improvement in the flap closure and maintenance of the lining membrane was obtained by microsurgery.

Wachel et al. ${ }^{12}$ evaluated periodontal regeneration in 11 patients with bilateral infra bony defects. The patients were divided into 2groups: one subjected to Endogain $\AA$ and microsurgery, and a control group subjected only to microsurgery. Patients were evaluated on oral hygiene, bleeding on probing, probing depth, clinical attachment level and gingival recession at baseline, and for 6 and 12 months. The rate of healing was also assessed within one and two weeks, which evaluates the coaptation of surgical wounds. The primary closure flaps reached $89 \%$ and $96 \%$ for the test group and control, respectively. Both techniques associated microsurgery result in large percentage of maximum primary closure and tissue preservation.

Francetti et al..$^{13}$ investigated 16 cases of gingival coverage using the slide coronary associated with free rotation of the papilla. Patients were evaluated at baseline and after 12 months for recession, probing depth, and clinical attachment level. The recessions decreased from $3.38 \pm 0.72 \mathrm{~mm}$ to $0.13 \pm 0.29 \mathrm{~mm}$, with mean coverage of $97.03 \%$ of the total cases, and only three cases did not reach $100 \%$ coverage. The authors have stated the microscope is an invaluable tool, improving visual acuity, manipulation of tissue and sutures, making surgery less traumatic, favoring the prognosis.

It is reasonable to assume that the microsurgical approach for root coverage may be related to a more predictable regenerative process, because the enhanced visual acuity by using the operating microscope and the use of specifically designed microsurgical instruments can reduce tissue trauma, which improves the vascularization, and increases the possibility of obtaining and maintaining primary wound closure, thus allowing the optimal biologic activity. However, it is impossible to assess the nature of the attachment with clinical examinations; hence, further histologic studies are necessary to evaluate this hypothesis ${ }^{5,14}$.

\section{Conclusion}

Surgeons can incorporate microsurgery in their daily practice. However, a training period is required, thus the costs of these devices should be considered. Regardless of the methodology, great aesthetic results and a reduction in repair time and discomfort for the patient are observed. Although microsurgical procedures offer the advantage of improved visual acuity, less traumatic handling of the soft tissue and precise wound closure, thus allowing for healing by primary intention, it demands time and increases the treatment costs.

\section{References}

1. Barraquer JL Jr. Technique of penetrating keratoplasty. Am J Ophthalmol 1950,33:6-17.

2. Belcher JM. A perspective on periodontal microsurgery. Int $\mathbf{J}$ Periodontics Restorative Dent 2001;21:191-6.

3. Carr GB. Microscopes in endodontics. J Calif Dent Assoc 1992;20:55-61.

4. Rubinstein R. The anatomy of the surgical operating microscope and operating positions. Dent Clin North Am 1997;41:391-413.

5. Andrade PF, Grisi MF, Marcaccini AM, Fernandes PG, Reino DM, Souza SL, Taba M, Palioto DB, Novaes AB. Comparison between micro- and macrosurgical techniques for the treatment of localized gingival recessions using coronally positioned flaps and enamel matrix derivative. J Periodontol 2010;81:1572-9.

6. Tibbetts LS, Shanelec DA. An overview of periodontal microsurgery. Curr Opin Periodontol 1994:187-93.

7. Nordland WP. The role of periodontal plastic microsurgery in oral facial esthetics. J Calif Dent Assoc 2002;30:831-7.

8. Burkhardt R, Hurzeler MB. Utilization of the surgical microscope for advanced plastic periodontal surgery. Pract Periodontics Aesthet Dent 2000;12:171-80.

9. Tibbetts LS, Shanelec D. Periodontal microsurgery. Dent Clin North Am 1998;42:339-59.

10. Tibbetts LS, Shanelec D. Current status of periodontal microsurgery. Curr Opin Periodontol 1996;3:118-25.

11. Cortellini P, Tonetti MS. Microsurgical approach to periodontal regeneration. Initial evaluation in a case cohort. J Periodontol 2001;72:559-69. 
12. Wachtel H, Schenk G, Bohm S, Weng D, Zuhr O, Hurzeler MB. Microsurgical access flap and enamel matrix derivative for the treatment of periodontal intrabony defects: a controlled clinical study. J Clin Periodontol 2003;30:496-504.

13. Francetti L, Del Fabbro M, Testori T, Weinstein RL. Periodontal microsurgery: report of 16 cases consecutively treated by the free rotated papilla autograft technique combined with the coronally advanced flap. Int J Periodontics Restorative Dent 2004;24:272-9.

14. Burkhardt R, Lang NP. Coverage of localized gingival recessions: comparison of micro- and macrosurgical techniques. J Clin Periodontol 2005;32:287-93. 